\title{
腎不全診療開始時期が及ぼす透析導入期医療への 影響について
}

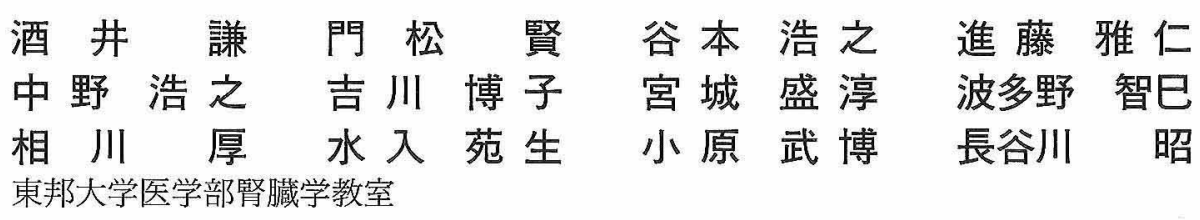

key words：腎不全診療，慢性腎不全，血液透析，透析導入期，医療経済

〈要旨〉

末期腎不全患者の合併症なき円滑な透析導入もまた腎臟專門医の責務のひとつである．今回私たちは腎不全診療 開始時期から透析導入までの期間が及ぼす医学的ならびに経済的側面への影響について検討した。

1994 年から 1997 年まで当院にて新規に血液透析を導入した全 120 名を対象として 1$)$ Early 群 $(n=38)$ : 透析導 入 1 年前以前の腎臓專門医への紹介診療開始群 2$)$ Intermediate 群 $(n=41)$ : 透析導入 1 か月前以前, 1 年未満の 紹介診療開始群 3) Late 群 $(n=41)$ : 透析導入前 1 か月未満の紹介診療開始群, の3 群に分けて患者背景, 初診 時および導入時の BUN, 血清 creatinine 值, 導入時の平均在院日数と一日平均医療費, 内シャントの有無, 初回透 析での除水量につき検討した.

その結果 3 群間では Late 群で在院日数が有意に長く(Late：47日, Intermediate 群：29 日, Early 群：31 日), 一日当たりの医療費が有意に高額であった（Late 群：46212 円, Intermediate 群：38558 円, Early 群：37927 円). また初回透析時にすでに内シャントのある患者は Early, Intermediate 群で $80 \%$ 以上, Late 群では $39 \%$ でった。 初回透析の平均除水量は, Early 群で $1.18 \mathrm{~kg}$, Intermediate 群で $1.34 \mathrm{~kg}$, Late 群では $2.0 \mathrm{~kg}$ と段階的に増加した。 導入時の血清 creatinine 值には各群で差異はなかったが，BUN は Early 群から Late 群へと有意に増加した。

したがってより早期，少なくとも Intermediate 群に相当する初診時期（血清 creatinine $5.9 \mathrm{mg} / \mathrm{d} l$ ）までの腎不 全診療の開始は，谷の後の透析導入を医学的にも医療経済側面からも容易にさせ得ると考えられた.

\section{Cost and morbidity analysis regarding referral pattern in ESRD patients starting hemodialysis}

Ken Sakai, Satoshi Kadomatsu, Hiroyuki Tanimoto, Masahito Shindo, Hiroyuki Nakano, Hiroko Yoshikawa, Moriatsu Miyagi, Tomomi Hadano, Atsushi Aikawa, Sonoo Mizuiri, Takehiro Ohara, Akira Hasegawa

Department of Nephrology, Toho University School of Medicine

Late referral of patients with end stage renal disease (ESRD) has resulted in increased cost, morbidity and even mortality. As the population of ESRD patient increases, it becomes more important to determine when physicians should refer those patients to a nephrologist. In an effort to examine the relationship between referral patterns and therapeutic impact on cost as well as morbidity, we analyzed renal function at the initial visit and on initiating dialysis, status of blood access, and dose of ultrafiltration at the initial dialysis. We also analyzed cost and duration of hospital stay to initiate dialysis for each referral pattern.

From 1994 to 1997, a total of 120 patients entered chronic hemodialysis therapy at this institution and these subjects were divided into three groups. 1) early referral $(n=38,61 \pm 14 \mathrm{yrs})$ : referred more than one year before initiation of dialysis 2 ) intermediate referral ( $n=41,62 \pm 10 \mathrm{yrs})$ : less than 1 year and more than one

酒井＼cjkstart謙 東邦大学医学部腎臓学教空％ 143-8540 大田区大森西 5-21-16 (03-3762-4151)

Ken Sakai Fax 03-5471-3056

〔受付：平成 11 年 3 月 30 日，受理：平成 11 年 10 月 13 日〕 
month before dialysis 3 ) late referral $(n=41,60 \pm 13$ yrs) : less than one month before dialysis was initiated.

Mean hospital stay was significantly longer in the late referral group (47 days), and the daily hospital cost for initiating dialysis was higher than those of the early and intermediate groups (late : 46212 yen vs int : 38558 yen, $p=.004$, late vs early : 37927 yen, $p=.005$ ). Already prepared AV fistula was $82 \%$ for the early, $90 \%$ for the intermediate, $39 \%$ for the late referral group. The dose of ultrafiltration at the initial dialysis was $1.18 \mathrm{~kg}$ for the early, $1.34 \mathrm{~kg}$ for the intermediate, $2.0 \mathrm{~kg}$ for the late referral group.

Our results strongly suggest that referral at the earliest opportunity would decrease cost and lower morbidity for ESRD patients.

\section{緒 言}

末期慢性腎不全患者の腎臓専門医による診療が適切 な時期から開始されることは，透析導入に際しての患 者の精神的, 身体的, 経済的な負担を極力避ける上で 大変重要である. 18 万人を越えるわが国の透析患者の 導入時の原疾患は近年, 慢性系球体腎炎などの原発性 腎疾患の相対的低下の一方で糖尿病や腎硬化症の増加 が顕著であり ${ }^{11}$ ，その保存期治療が腎臓専門医以外に より行われる場合が少なくない，今回腎臟病診療開始 から透析導入までの過程をその紹介時期に分けて検討 し，末期腎不全患者にとって医学的，経済的に適確な 腎不全診療開始時期を検討した。

\section{I 。対象および方法}

1994 年 1 月から 1997 年 12 月までの当院における 全 137 名の新規慢性透析導入患者を婜臓專門医での腎 不全診療開始時期別に分けて検討した。留臟病のその 特殊性により，肉眼的血尿や浮腫などの自覚症状を除 いてそのほとんどが院内他科や院外施設からの紹介が 受診の動機であるため, 紹介時期別に診療開始時期を 定義した．紹介䛦療開始時期とは腎臟科外来診療録上 の初診日とし，その後の腎臓專門医による継続診療が 行わ机た条件のもと，透析導入までの期間により次の 3 群に区分した。なお透析導入基準は厚生科学研究腎 不全医療研究班案 ${ }^{2}$ に照らして適切に行われた。

1) Early 群: 47 人(血液透析導入 38 人, 腹膜透析 導入 9 人)

透析導入の 1 年以上前より腎臓專門医による腎不全 診療を開始した群

2) Intermediate 群：46人(血液透析導入 41 人, 腹 膜透析導入 5 人)

透析導入の 1 か月以上前より 1 年未満の間で腎臟專 門医による腎不全診療を開始した群

3) Late 群： 44 人（血液透析導入 41 人，腹膜透析 導入 3 人)
透析導入までの 1 か月未満の間で腎臓専門医による 腎不全診療を開始した群

これら各群において診療録にて以下の項目について 調查した。

（1）患者背景（原疾患，糖尿病の有無）

（2）院内または院外施設からの紹介割合

(3) 透析導入時における内シャントの有無

（4）紹介初診時および透析導入時の BUN，血清 creatinine 值, 導入時の BUN/血清 creatinine 比

（5）初回透析時の除水量

（6）全症例および糖尿病，非糖尿病別の導入時に要 した入院費用，入院日数

（7）透析導入日より 1 年間の観察期間における死亡 例

原疾患区分は triopathy のそろった糖尿病性腎症， 腎生検で確定した慢性系球体腎炎，明らかな高血圧歷 の後に発症した腎硬化症, 画像彰断により明らかな多 発性囊胞腎，その他とした，血液透析導入後は全例退 院後に関連透析施設に転出し，その後の予後に関する 調査は転出透析施設へ照会した。

入院費用調查は透析導入時の入院で要した全保険点 数を診療報酬記録より調べ，導入時に要した入院診療 実日数で一日医療費に換算し, 各群で比較検討した。 な招ここでいう医療費とはあくまでも診療報酬請求に おける保険点数上の単純計算であり当然個及の患者や 医療機関双方の医学的社会的事情に依存する。 した がって 3 次救急医療, 高度先端医療, 教育機関という 側面をもつ一大学病院の医療費統計が，わが国全体の 腎不全医療経済を必ずしも反映するものではない.

なお今回調查期間中に腹膜透析を導入した 17 名に ついては導大後も当施設にて全例経過観察を行ってい るが，導入時の入院費用，入院日数を血液透析と同一 評価できないため今回の調査から除外し，別途検討し た.

各群の結果はすべて平均值士標準偏差で示し, 統計 解析は群間比較を unpaired Student $-t$ 検定にて行い 危険率 $5 \%$ 以下を有意とした。 
表 1 患者背景

\begin{tabular}{lccccc}
\hline & 導入までの期間 (月) & 症例数 & 性別 (男 : 女) & 年齢 (歳) & $\begin{array}{c}\text { 院外からの } \\
\text { 紹介率 (\%) }\end{array}$ \\
\hline Early 群 & $67.44 \pm 51.63$ & 38 & $25: 13$ & $61 \pm 14$ & $29(76 \%)$ \\
Intermediate 群 & $5.56 \pm 3.03$ & 41 & $32: 9$ & $62 \pm 10$ & $23(56 \%)$ \\
Late 群 & $0.09 \pm 0.30$ & 41 & $19: 22$ & $60 \pm 13$ & $26(63 \%)$ \\
\hline
\end{tabular}

表 2 原疾患分類

\begin{tabular}{lcccccc}
\hline & $\begin{array}{c}\text { 糖尿病 } \\
(\mathrm{n}=42)\end{array}$ & $\begin{array}{c}\text { 慢性腎炎 } \\
(\mathrm{n}=46)\end{array}$ & $\begin{array}{c}\text { 腎硬化症 } \\
(\mathrm{n}=21)\end{array}$ & $\begin{array}{c}\text { 多発霬胞腎 } \\
(\mathrm{n}=4)\end{array}$ & $\begin{array}{c}\text { その他 } \\
(\mathrm{n}=7)\end{array}$ & 計 \\
\hline Early 群 & $5(13 \%)$ & $18(47 \%)$ & $9(24 \%)$ & $4(11 \%)$ & $2(5 \%)$ & $38(100 \%)$ \\
Intermediate 群 & $20(49 \%)$ & $14(34 \%)$ & $6(15 \%)$ & $0(0 \%)$ & $1(2 \%)$ & $41(100 \%)$ \\
Late 群 & $17(42 \%)$ & $14(34 \%)$ & $6(15 \%)$ & $0(0 \%)$ & $4(9 \%)$ & $41(100 \%)$ \\
\hline
\end{tabular}

注）气の他の疾患：多発動脈炎 1 例，悪性高血圧 2 例，慢性腎孟腎炎 1 例，肝硬変 2 例，慢性関節りウマ 于1例

表 3 各群における初診時血清 creatinine 值と血液透析導入時の状況

\begin{tabular}{|c|c|c|c|c|c|c|}
\hline & $\begin{array}{l}\text { 初診時血清 } \\
\text { creatinine 值 }\end{array}$ & $\begin{array}{l}\text { 導入時血清 } \\
\text { creatinine 值 }\end{array}$ & $\begin{array}{l}\text { 導入時 } \\
\text { BUN 值 }\end{array}$ & $\begin{array}{l}\text { 導入時 } \\
\text { BUN/Cr 比 }\end{array}$ & 初回除水量 & $\begin{array}{l}\text { 導入時シャ } \\
\text { ント作成率 }\end{array}$ \\
\hline Early 群 & $\begin{array}{l}3.09 \pm \\
\quad 2.17 \mathrm{mg} / \mathrm{d} l\end{array}$ & $\begin{array}{l}10.13 \pm \\
2.53 \mathrm{mg} / \mathrm{d} l \text { 的 }\end{array}$ & $\begin{array}{l}87.00 \pm \\
\quad 25.80 \mathrm{mg} / \mathrm{d} l^{*}\end{array}$ & $9.01 \pm 3.37$ 的的 & $1.2 \pm 1.2 \mathrm{~kg}^{* *}$ & $82 \% * * *$ \\
\hline Intermediate 群 & $\begin{array}{l}5.91 \pm \\
\quad 2.11 \mathrm{mg} / \mathrm{d} l\end{array}$ & $\begin{array}{l}10.79 \pm \\
\quad 3.34 \mathrm{mg} / \mathrm{d} l\end{array}$ & $\begin{array}{l}94.73 \pm \\
21.16 \mathrm{mg} / \mathrm{d} l\end{array}$ & $9.41 \pm 3.26$ & $1.3 \pm 1.2 \mathrm{~kg}$ & $90 \%$ \\
\hline Late 群 & $\begin{array}{l}9.62 \pm \\
\quad 3.87 \mathrm{mg} / \mathrm{d} l\end{array}$ & $\begin{array}{l}10.72 \pm \\
\quad 3.90 \mathrm{mg} / \mathrm{d} l^{\text {s }}\end{array}$ & $\begin{array}{l}98.73 \pm \\
\quad 31.82 \mathrm{mg} / \mathrm{d} l^{*}\end{array}$ & $10.0 \pm 3.07$ 的的 & $2.0 \pm 1.5 \mathrm{~kg}^{* *}$ & $39 \% * * *$ \\
\hline
\end{tabular}

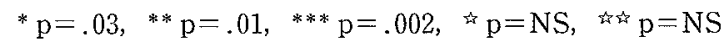

\section{II. 結 果}

腹膜透析導入患者 17 名を除いた計 120 名の血液透 析導入患者の 3 群間の患者背景は表 1 に示すとおり, 各群とも 61 歳前後で導入され平均年齢に統計学的差 異はなかった，性別では Early 群でも Intermediate 群でも男性患者が多かった（それぞれ男性 65\%，78\%) のに対して Late 群では男女比が逆転して（男性 46\%， 女性 $54 \%$ ）その多くは女性であった，また今回の入院 日数，費用の検討から除外した腹膜透析の割合は， Early 群の 9 人 $(20 \%)$, Intermediate 群の 5 人 $(11 \%)$, Late 群の 3 人 ( $7 \%)$ であり, 統計学的差異 はないが早い紹介時期の患者群がより腹膜透析を選択 した。また各群で院外の各施設からの紹介率（表 1) を検討してみると, Early 群で 29 人 (76\%), Intermediate 群で 23 人 $(56 \%)$, Late 群で 26 人 $(63 \%)$ であ り,よって常に半数以上が地域の誩療所や透析施設の ない病院からの紹介による慢性腎不全であった。

原疾患の比較であるが (表 2)，糖尿病の比率は Early 群で $13 \%$ と有意に低く, Intermediate, Late 群 ではそれぞれ 49\%，42\%であった（Early vs Late,
Intermediate 群 : $\mathrm{p}=.003)$ ，一方腎生検により確定 された慢性系球体腎炎は Early 群で 47\%であったが, Intermediate, Late 群ではそれぞれ 34\%であった。ま た多発性囊胞腎の 4 症例はすべて Early 群に含まれ ていた，以上のことより，糖尿病全 42 例の腎不全殓療 開始時期は透析導入までの 1 年末満にその 37 例 (88\%) が集中しており，反対に慢性系球体腎炎，腎硬 化症および多発性囊胞腎は早期に腎臓専門医による腎 不全診療が開始されていた。

紹介初診時の平均血清 creatinine 值は（表 3 ）, Early 群では $3.0 \mathrm{mg} / \mathrm{d} l$, Intermediate 群で $5.9 \mathrm{mg} /$ $\mathrm{d} l$, Late 群では $9.6 \mathrm{mg} / \mathrm{d} l$ であった.これに対して初 回導入時の平均血清 creatinine は 3 群間でそれぞれ $10.1,10.8,10.7 \mathrm{mg} / \mathrm{d} l$ であり統計学的差異はなかっ た。一方導入時の平均 BUN 值は 87.0, 94.7, $98.7 \mathrm{mg} /$ $\mathrm{d} l$ と Early から Late にかけて有意に増加した（Late vs Early 群: $\mathrm{p}=.03$ ).

同様にBUN/creatinine 比も Early 群では 9.01, Intermediate 群で 9.41, Late 群では 10.06 と統計学 的には有意でないが上昇傾向がみられ, 診療開始時期 が遅くなるとより導入時の異化无進状態が強くなると 考えられた。 


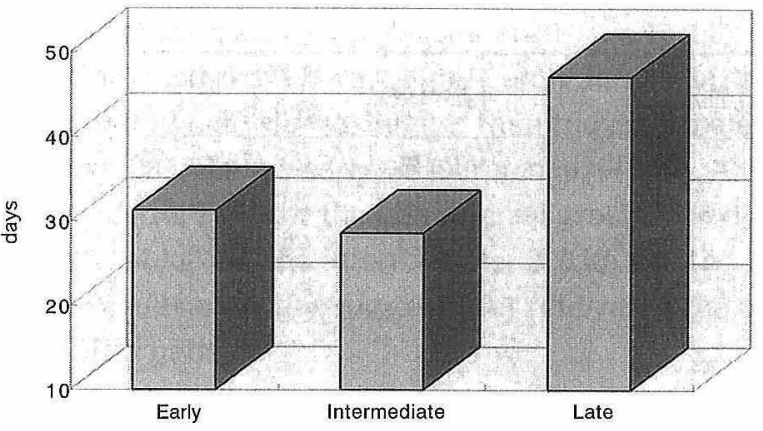

図 1 各群における血液透析導入時の平均在院日数 Early 群：31.3土22.4日, Intermediate 群： $28.6 \pm 23.7$ 日, Late 群: $47.1 \pm 37.3$ 日, Late vs Intermediate 群 $: \mathrm{p}=.008$, Late vs Early 群： $\mathrm{p}=.025$

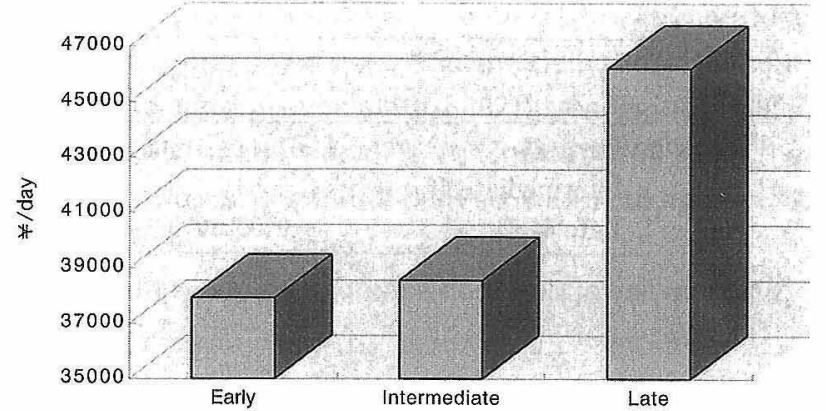

図 2 各群における血液透析導入時の一日当たり の平均医療費

Early 群：37927 \pm 11964 円, Intermediate 群：38558土9065 円, Late 群 : 46212士 13988 円, Late vs Intermediate 群: $\mathrm{p}=.004$, Late vs Early 群 $: \mathrm{p}=.005$, Early vs Intermediate 群 $: \mathrm{p}=.79$

表 4 糖尿病, 非糖尿病別の血液透析導入時の平均在院日数と一日医療費, 紹介様式㧍よび予後

\begin{tabular}{|c|c|c|c|c|c|}
\hline & & 平均在院日数 & $\begin{array}{c}\text { 一日平均医療費 } \\
\text { (円） }\end{array}$ & $\begin{array}{l}\text { 院内外から } \\
\text { の紹介比率 }\end{array}$ & $\begin{array}{l}\text { 導入後 } 1 \text { 年 } \\
\text { 間の死亡数 }\end{array}$ \\
\hline 糖尿病 & Early 群 $(\mathrm{n}=5)$ & $37.8 \pm 7.6$ & $42538 \pm 4736$ & $\begin{array}{l}\text { 院内 } 60 \% \\
\text { 院外 } 40 \%\end{array}$ & 1 \\
\hline \multirow[t]{2}{*}{$n=42$} & Intermediate 群 $(\mathrm{n}=20)$ & $34.6 \pm 29.1^{*}$ & $39782 \pm 8127$ 나 & $\begin{array}{l}\text { 院内 } 55 \% \\
\text { 院外 } 45 \%\end{array}$ & 0 \\
\hline & Late 群 $(\mathrm{n}=17)$ & $63.1 \pm 50.1^{* \diamond}$ & $45844 \pm 14074$ 하 & $\begin{array}{l}\text { 院内 } 70 \% \\
\text { 院外 } 30 \%\end{array}$ & 3 \\
\hline 非糖尿病 & Early 群 $(\mathrm{n}=33)$ & $30.3 \pm 23.8$ & $37228 \pm 12605$ & $\begin{array}{l}\text { 院内 } 12 \% \\
\text { 院外 } 88 \%\end{array}$ & 2 \\
\hline \multirow[t]{2}{*}{$\mathrm{n}=78$} & Intermediate 群 $(n=21)$ & $22.6 \pm 15.3^{* *}$ & $37392 \pm 9934^{* * *}$ & $\begin{array}{l}\text { 院内 33\% } \\
\text { 院外 } 67 \%\end{array}$ & 0 \\
\hline & Late 群 ( $(\mathrm{n}=24)$ & $36.3 \pm 20.4^{* * \bullet}$ & $46553 \pm 1422^{* * *}$ & $\begin{array}{l}\text { 院内 } 12 \% \\
\text { 院外 } 88 \%\end{array}$ & 0 \\
\hline
\end{tabular}

${ }^{*} \mathrm{p}=.03,{ }^{* *} \mathrm{p}=.01, * * * \mathrm{p}=.01,{ }^{\diamond} \mathrm{p}=.02, * \mathrm{p}=\mathrm{NS}$

この血液透析導入時における内シャントの有無に関 する検討（表 3 ）では，初回透析時に内シャントによ る透析を行った割合は, Early 群では $82 \%$, Intermediate 群では 90\%であった。一方で Late 群では 39\%と 他の 2 群に比して有意に少なかった $(\mathrm{p}=.002)$ 。した がって Late 群の $61 \%$ は透析用カテーテルの挿入を 行っていわゆる緊急透析を行って扔り, 後に内シャン 卜作成を行ったことになる。

初回透析時の平均除水量の検討 (表 3 ) では, Early 群では $1.18 \pm 1.23 \mathrm{~kg}$, Intermediate 群で $1.34 \pm 1.23$ $\mathrm{kg}$, Late 群では $2.0 \pm 1.5 \mathrm{~kg}$ と段階的に有意に増加 した（Late vs Early群 $: \mathrm{p}=.01$, Late vs Intermediate 群 : $\mathrm{p}=.003)$.

次に透析導入のために要した平均入院日数は Late 群では 47.1 日であり, 他の 2 群（Early 群 31.3 日, Intermediate 群 28.6 日）に比して有意に長かった (Late vs Intermediate 群 $: p=.008$, Late vs Early
群： $\mathrm{p}=.025)($ 図 1 ).

このときに要した一日平均医療費は Late群で 46212 円, Intermediate 群で 38558 円, Early 群で 37927 円であった（Late vs Intermediate 群： $\mathrm{p}=.004$, Late vs Early群: $\mathrm{p}=.005)$. Early 群と Intermediate 群では差異はなかった $(\mathrm{p}=.79)$ (図 2 ).

これらの入院日数, 一日平均医療費学糖尿病 (42 例)，非糖尿病 (78 例) に分けて検討した結果（表 4), Late 群では Intermediate 群に比し糖尿病, 非糖尿病 ともに入院日数が有意に長かった。一日平均医療費は 非糖尿病でのみ Late 群は Intermediate 群に比し有 意に高額であった。また同じ Late 群における糖尿病 および非糖尿病両者の比較では入院費用には有意差は なかったが，入院日数については有意に糖尿病では長 かった（糖尿病 $63 \pm 50$ 日，非糖尿病 $36 \pm 20$ 日： $\mathrm{p}=.02)$. したがって糖尿病の有無にかかわらず Late 群では入院日数が長く, 特に糖尿病でその傾向が強 
表 5 - 透析導入後一年間に掠的る死亡例の内訳

\begin{tabular}{|c|c|c|c|c|c|c|c|}
\hline 症 & 例 & 年齢性別 & 原 疾 患 & 初診日 & 透析導入日 & 死 & $\begin{array}{l}\text { 導入から死亡まて } \\
\text { の期間 }\end{array}$ \\
\hline Early 群 & 羊 (1) & 58 歳男 & 慢性敉炎 & 1983.3 .28 & 1994.3 .27 & 脳出血 & 1 加月（入院中） \\
\hline Early 群 & 羊 (2) & 78 歳男 & 糖尿病 & 1990.7 .12 & 1995.3 .24 & 心不全 & 11 少月 \\
\hline Early 群 & 羊 (3) & 72 歳男 & 㯏硬化症 & 1991.3 .25 & 1993.3 .8 & 胃癌穿孔 & 6 加月 \\
\hline Late 群 & (1) & 71 歳女 & 糖尿病 & 1996.6 .7 & 1996.6 .7 & 消化管出血 & 4 加（入院中） \\
\hline Late 群 & (2) & 72 歳男 & 糖尿病 & 1994.5 .7 & 1994.5 .20 & 急性循環不全 & 7 加月 \\
\hline Late 群 & (3) & 60 歳男 & 糖尿病 & 1994.8 .13 & 1994.8 .13 & 急性心筋梗塞 & 1 週間 (入院中) \\
\hline
\end{tabular}

かった。糖尿病および非糖尿病両者の腎不全診療は, 糖尿病では常に院内から, 非糖尿病では逆に常に院外 からの紹介が半数以上を占めていた，また導入後の一 年間における予後は表 4 亿示すように糖尿病で 4 例, 非糖尿病で 2 例の死亡例が確認された。

その死亡例の内訳であるが(表 5), Late 群と Early 群にそれぞれ 3 例ずつ計 6 例であり，特に透析導入後 に退院できずに合併症にて死亡した症例は 3 例で，1 例は Early 群の非糖尿病患者(脳出血により死亡)，他 2 例はいずれも Late 群の糖尿病患者（1 例は急性心管 梗塞，1例は消化管出血で死亡）であった。

\section{III. 考 察}

当施設は東京都 23 区の南部に位置し, 地域の中核と して全科診療を行う標準的な大学病院の一診療科であ る. 1980 年より腎臟科単科としての独立した標傍を有 し, 腎藏内科, 泌尿器科, 小児科医が一体となり, 蛋 白尿血尿という腎臟病の入り口より，腎不全，透析療 法を経て腎移植までを一貫して行う腎臟病総合医療を 行っている. 地域の他施設よりの紹介率は約 $60 \%$ あ゙ り(表 1)，これに各科からの紹介を含めると初診の約 80\%以上が紹介患者で占められる。したがって紹介時 期別による腎不全医療開始時期の検討に十分値する診 療科であると考える。

わが国の導入時の原疾患は近年，慢性系球体腎炎な ぞの原発性腎疾患は 1987 年は $54.2 \%, 98$ 年では $35.0 \%$ と漸次低下し，その一方で糖尿病は $22.1 \%$ から $35.7 \%$ ，腎硬化症は $3.9 \%$ から $6.7 \%$ へ増加した 1 . したがってその保存期治療が腎臟専門医以外により行 われる場合が少なくないことが容易に予想される，本 検討でも糖尿病性腎症による導入患者 42 例の腎不全 診療開始時期は透析導入までの 1 年未満に 37 例 (88\%)（表 2)が集中していた。このわずか一年間とい う短期間で患者は糖尿病の食事療法から高エネルギー の腎臟食へ移行し, 長く診療に携わり信頼関係のある 一般内科あるいは糖尿病專門医から腎臟專門医へ治療
の主体が移る，そして進展防止に努めながらも末期に 至る腎不全管理を行うという極めて不安定な日々を過 ごすことになる。一般に糖尿病性腎不全は非糖尿病性 腎不全に比較して検査成績よりも臨床症状が先行して 血清 creatinine 值が $8.0 \mathrm{mg} / \mathrm{d} l$ 以下で透析導入され る場合が少なくない て, 血清 creatinine $5.0 \mathrm{mg} / \mathrm{d} l$ より透析に至るまでの 期間は, 慢性腎炎に由来する腎不全の $9.0 \mathrm{mg} / \mathrm{d} l$ より 透析に至るまでの期間に相当し，少なくとも $5.0 \mathrm{mg} /$ $\mathrm{d} l$ の時点でのシャント作成が望ましいといわれる4). したがって導入時の平均血清 creatinine 值の低い糖 尿病で腎臟専門医による腎不全診療がむしろ早期に行 われない現実は，糖尿病専門医と腎臟専門医の連携の 強化を一層促すものと考元られる，その一方で慢性系 球体腎炎, 腎硬化症および多発性囊胞腎は早期㭴㹂 専門医による腎不全診療が開始されていた(表 2 )。特 に腎生検により診断された慢性系球体腎炎全 46 例の

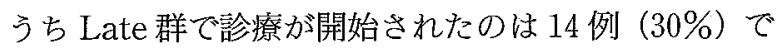
あり，他の70\%は長期にわたって経過を観察し得た。

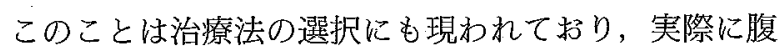
膜透析を導入した 17 例(糖尿病 2 例, 慢性系球体腎炎 15 例) の内訳は, Early 群の $20 \%$ ( 9 人), Intermediate 群の $11 \%$ ( 5 人), Late 群の $7 \%$ (3 人) であり, 早い 紹介時期の患者群がより腹膜透析を選択する時間的余 裕があったことが伺われる，糖尿病による腹膜透析導 入は 2 例のみであったがいずれも Intermediate 群に 含まれていた。このことは糖尿病性腎症であっても十 分な時間をかければ腹膜透析を選択しうることを意味 し, 治療法の選択という観点からも早期の腎臓専門医 による腎不全診療の開始が望まれる。

Schmidt $ら^{5}$ は全透析導入患者 238 例中の診療開始 時期と治療法の選択に関する検討を行った，その結果 Late 群の 58 例中わずかに 5 例 ( $9 \%$ ) のみが当初腹膜 透析を選択したが， 4 か月後に血液透析から腹膜透析 へ移行した例がさらに 11 例あり結果的に合計 16 例 (28\%)方腹膜透析を選択したと報告した。これは緊急 あるいは緊急に準ずる状況で血液透析導入をした 
Late 群であっても潜在的に腹膜透析を選択する患者 は存在することを意味する。我々の Late 群において は血液透析導入後に腹膜透析に移行した例はなかった が，当初の透析方法の選択がその後の治療法を決定す る傾向 ${ }^{6}$ は腎臓専門医の側に多分に責任があると思わ れる。すすなわち全透析患者の $5 \%$ 程度でしかないわが 国の腹膜透析の状況やわが国の貧困な腎移植の状況を 考えるとき，我及は腎不全診療開始時期にかかわらず 透析導入以降もずっと常に患者に情報を与光透析治療 法や腎移植への選択の機会を作る努力が肝要である.

今回の患者背景の調査で半数以上が院外からの紹介 診療であったが, Early群でも Intermediate 群でも男 性患者が多かったのに対してLate 群では女性が多 かった(表 1)。これは職場検診などから受診の機会の ある男性に比して女性が自覚症状の出現により地域の 病医院をはじめて受診し紹介されるという形態を示し ているのかもしれない.

わが国の新規透析導入患者の動向であるが，鈴木 $ら^{77}$ にる調查によると 23 例の新規導入患者で全例 厚生科学研究腎不全医療研究班案沿沿って導入され, $28 \pm 9$ 日の入院日数であったという. 我々の検討（図 1)でも Early 群, Intermediate 群では 30 日前後の入 院日数であり, 全国の神経科入院を除くすべての平均 在院日数統計 ${ }^{8}$. (平均 32.8 日) と比較しても標準的で あるといえる．医学的にも透析導入後 1 加というの は蛋白異化が同化に転じ, 食欲が増進して理想体重も 増加しはじめその後血圧が安定してくる時期であ る9. しかし Late 群においては表 3 亿明らかなように 透析カテーテルの挿入による緊急透析とその後の内 シャント手術, 初回除水量にみられる溢水状態, BUN/ creatinine 比にみられる蛋白異化元進状態が存在し尿 毒症からの回復にかなりの日数（平均 47.1 日）がか かったものと思われる。さらに肺炎やカテーテル感染, 高カリウム血症, 消化管出血, 進行した腎性貧血, 困 難な高血圧管理などの可能性からも，入院費用が他の 2 群に比して 1.5 倍と高額 (図 2 ) になったことが予想 される.

以上の入院日数, 入院医療費の調査において糖尿病 症例 42 例と非糖尿病症例 78 例に分けて検討すると表 4 のごとく, 糖尿病非糖尿病ともに Late 群になると入 院日数が有意に長くなる。 よって早期の腎不全診療の 開始の重要性は糖尿病の有無を問わない普遍的な事実 と考元られた，しかし糖尿病の Late 群の平均在院日 数は 63 日で, 非糖尿病の 36 日に比してさらに有意に 長く, 一日平均医療費に差がなくても結果的に糖尿病 では総医療費は高額になることがわかる。
また非糖尿病症例では院外からの紹介が常に半数以 上を占め表 1 に示す症例全体の傾向と一致したが，糖 尿病では逆に院内からの紹介比率が常に半数以上で あった(表 4)。これ腎臟科という標傍の特殊性によ り当然慢性腎炎を中心とした腎単独疾患は院内外を問 わずに紹介されたと考元られ，一方の糖尿病性腎症に 関しては院内の各内科の糖尿病専門医による腎不全進 行抑制を目的とした加療が行われ，院内を経由して腎 不全期に腎臟科に紹介されることが多いことを示して いる，このような詠療形態はわが国の各施設にて普遍 的ではないと考元られるが，今後医療機関に抢けるこ の藏器病態別診療は進んで行くと思われ, 今回の検討 はとの弊害としての側面をもつ. しかしすでに第一位 になってしまった透析導入疾患の糖尿病 ${ }^{1}$ に関して は, 是非とも両專門医の連携が透析導入後も含めて計 られるべきであろう。

Late群において増大する入院日数や費用に関して は欧米でも同様の結果が得られており 5,10,11), 致死率で さえ高いという報告例もある ${ }^{10)}$. 我々の今回の検討で は導入後 1 年以内の死亡は Early 群, Late 群ともに 3 例ずつであり, 紹介診療開始時期と致死率との関係は 存在しなかった(表 5 ). しかし導入時の入院中の死亡 3 例のうち 2 例は Late 群の糖尿病症例であり, いずれ も初診日に緊急透析を行っている。腎不全診療開始時 期と各々の合併症との因果関係は不明であるが, Late 群の糖尿病症例は比較的重症のまま緊急透析導入を行 いその後の回復過程で合併症を起こす可能性は否定で きないと思われた。

\section{結論}

透析導入を遅らせる努力の一方で，時期を逸しない 末期腎不全医療もまた重要である。早期の腎臓專門医 による腎不全診療の開始は緊急透析のリスクを避ける のみでなく, 患者との信頼関係の構築のなかで食事療 法の熟知, シャントの管理, 腎性貧血治療や副甲状腺 機能六進症の予防などを行う時間的余裕をもたらす。 またさらに血液あるいは腹膜透析の治療の選択や腎移 植への希望をもたらす，したがって早期，少なくとも Intermediate 群に相当する血清 creatinine $5.9 \mathrm{mg} /$ $\mathrm{d} l$ 程度までの腎臟専門医による腎不全診療の開始は 腎不全の進展防止のみならずその後の透析導入を医学 的にも医療経済側面からも容易にさせ得る。

\section{文献}

1）日本透析医学会統計調查委員会：わが国の慢性透析療 
法の現況(1998 年 12 月 31 日現在). 日本透析医学会編

2）川口良人：透析導入のガイドラインの策定と追跡調查 に関する研究。平成 4 年度厚生科学研究腎不全医療研 究事業研究報告書 (総合班長 三村信英), p 156-164, 国立佐倉病院，佐倉，1993

3）久保昌志, 田邊信明, 上野 精: 糖尿病腎不全症例の 透析導入時所見に関する検討. 透析会誌 $31: 145-149$, 1998

4）山崎親雄, 伊藤 晃：保存療法から血液浄化法への転 換期における諸問題一糖尿病性腎不全の場合 2 .血液 浄化開始に際しての患者への説明と援助 2 ) 腎臟病担 当医の立場から。臨桨透析 6:1555-1565，1990

5) Schmidt RJ, Domico JR, Sorkin MI, Hobbs G: Early referral and its impact on emergent first dialyses, health care costs, and outcome. Am J Kidney Dis $32: 278-283,1988$

6) Lacke C, Senekjian HO, Knight TF, Hatelid R, Frazier M, Baker P, Weinman EJ : Twelve month's experience with continuous ambulatory and intermittent peritoneal dialysis. Arch Intern Med 141:
187-190, 1981

7）鈴木好夫，日ノ下文彦，横山啓太郎，山田 明，小椋 陽介，三村信英：厚生科学研究・督不全医療研究班血 液透析導入基準案の導入期に扔ける妥当性の検討。透 析会誌 $28: 885-890,1995$

8）国民衛生の動向 45, p 84-88, 厚生統計協会編， 1998

9) Charra B, Bergstrom J, Scribner BH : Blood pressure control in dialysis patients : importance of the lag phenomenon. Am J Kidney Dis 32 : 720-724, 1988

10) Obrador GT, Pereira BJG : Early referral to the nephrologist and timely initiation of renal replacement therapy : A paradigm shift in the management of patients with chronic renal failure. Am J Kidney Dis $31: 398-417,1988$

11) Jungers $P$, Zingraff $J$, Page $B$, Alibouze G, Hannedouche $T$, Man NK : Detrimental effects of late referral in patients with chronic renal failure: A case-control study. Kidney Int 43 (Suppl 41) : s170173,1993 